\title{
GEORGE LANSBURY AND THE MIDDLESBROUGH ELECTION OF 1906
}

The different elements which came together to form the Labour Representation Committee ${ }^{1}$ in February 1900 were, when it came to party organisation, at once its strength and its weakness. Labour was not in the position of a totally new political party having to build up a political machine from scratch, rather the LRC was able to utilise and build upon existing organisations: these were the Independent Labour Party, the Fabian Society, those trade unions which supported the LRC, and trades councils throughout the country (the Social Democratic Federation disaffiliated from the LRC after little more than a year's membership). At both a local and a national level, however, these organisations were often hostile to each other, jealous of their independence and suspicious of attempts by the LRC Executive ${ }^{2}$ to control them.

The early history of the LRC in the North East of England has many examples of the result of these divisions within the Labour movement. In 1902 the Labour movement in Jarrow and the NEC had been hopelessly split over the question of whether Alexander Wilkie, Secretary of the Shipwrights' Union, or Peter Curran, General Organiser of the Gasworkers' Union, should be LRC candidate for Jarrow. This was much more than an inter-union squabble as Curran was a socialist and leading ILPer while Wilkie was a moderate trade unionist prepared to work closely with local Liberalism; Curran's adoption was therefore a victory for the more militant forces within the Labour movement.

Many trade unionists in the North East who supported the LRC were opposed to a complete break with Liberalism and especially wished to work harmoniously with the existing Liberal-Labour MPs. On the other hand the ILP branches were impatient with the links

1 Organisations such as the Labour Representation Committee, the Independent Labour Party and the Amalgamated Society of Engineers are, after their first mention, referred to by abbreviations LRC, ILP and ASE.

${ }^{2}$ Hereafter referred to as the NEC (National Executive Committee). 
with Liberalism and persistently pressed for a more militant and independent policy. As more LRC candidates were adopted so the situation became more tense, both between the LRC and the Liberal Party and between the factions within the LRC. Arthur Henderson, worried that the increasing number of LRC candidates, especially in South Durham, might result in a Liberal candidature at Barnard Castle, did his best in May 1903 to prevent Frank Rose of the Amalgamated Society of Engineers being adopted for Stockton on Tees. ${ }^{1}$

By the autumn of 1903 there was one LRC MP in the area, Arthur Henderson, and five candidates nominated and approved for Darlington, Stockton, Newcastle, Sunderland and Jarrow. There were in fact to be no more official LRC candidates in the area. ${ }^{2}$ In the spirit of the Gladstone-MacDonald agreement the Liberals had given way in Darlington and agreed to run only single candidates for the double member constituencies of Newcastle and Sunderland but this was as far as they were prepared to go. After the Gladstone-MacDonald agreement, of course, the NEC was not prepared to look kindly on a plethora of LRC candidates who would strain relations with the Liberals. This situation was not looked upon favourably by many members of the ILP in the area, especially as that organisation was now expanding in the North East, ${ }^{3}$ and 1904 and 1905 were to see efforts by the ILP to put forward candidates in Gateshead, ${ }^{4}$ Chesterle-Street ${ }^{5}$ and Middlesbrough.

George Lansbury's candidature for Middlesbrough in the 1906 election epitomises many of the problems facing the Labour movement in the North-East, the problems of an LRC which is in many ways a coalition of disparate groups many of them hostile to each other, the problems of many trade unionists, now affiliated to the LRC but still sympathetic to Liberalism and Liberal-Labour MPs, and the problems of many ILP branches, composed of socialist militants but tied to a party which for electoral purposes is in close alliance with Liberalism.

The two main problems confronting the LRC in the North East, as

${ }^{1}$ In the event, of course, Henderson had to face a Liberal candidate but he was very reluctant to do so. He was elected MP for Barnard Castle at a by-election in July 1903.

2 James Sexton of the Liverpool Dockers was adopted for Tynemouth but withdrew in 1904.

${ }^{3}$ In 1905 the ILP felt it worthwhile to send an area organiser to the North East. By April 1905 there were sixteen branches of the ILP in Durham.

4 In Gateshead there was strong pressure from the ILP for a candidate to oppose John Johnson, the candidate of the Durham Miners' Association and a "Lib-Lab".

5 J. W. Taylor, who was to be elected MP for Chester-le-Street in 1906, was also a DMA candidate but, unlike Johnson, he was a militant ILPer. 
elsewhere, in 1905 concerned its relationship with Liberalism and MacDonald's policy of keeping intact an unavowed electoral alliance and its perennial internal problem of reconciling the disparate groups of which it was composed. These two problems were linked in so far as to go too far towards an open electoral alliance risked the alienation of the more militant ILPers, while not to go far enough might not only destroy the alliance but lose the support of moderate trade unionists and potential Labour voters. ${ }^{1}$ This latter outcome was particularly likely in the North East, where working class Liberalism was so strong and where there was a tradition of Liberal-Labourism. The attempt by the ILP and LRC in Middlesbrough to get George Lansbury elected brought these problems into focus.

\section{II}

Middlesbrough was, between 1885 and 1918, the largest single member constituency in the North East. The town had grown faster than any other town in England during the later Victorian period, largely due to its iron industry which had grown up to exploit the iron ore of the Cleveland Hills. The parliamentary constituency of Middlesbrough, which was created in 1867, was considerably larger than the municipal borough and, according to Dr Pelling, was "almost but not quite predominantly working class". ${ }^{2}$ Between 1867 and 1918 a Conservative candidate was only once elected and on only one other occasion was a candidate elected who did not have the backing of local Liberalism; this was in 1892 when Joseph Havelock Wilson, the Secretary of the Seamen's Union, was elected as a Labour MP after a three cornered fight with a Liberal and a Liberal-Unionist. ${ }^{3}$ After this, however, Wilson concluded a rapprochement with local Liberalism and considerably modified his independent Labour position. When Wilson stood for the second time in $\mathbf{1 8 9 5}$ he was elected with the support of

1 The potential Labour voter was not, of course, always a Liberal (indeed in Lancashire he was more often likely to have been a working man with Unionist sympathies) but nationally and especially in the North East it is clear that the LRC expected votes to come from ex-Liberals rather than ex-Unionists. The exception to this in the North East was perhaps Teesside, where working class Unionism appears to have been strong. See below.

2 H. Pelling, Social Geography of British Elections (1967), p. 329.

3 Liberal Unionism. The Liberal Unionist Party had its origins in the split within the Liberal Party over Gladstone's first Irish Home Rule bill. The Liberals who opposed Home Rule formed the Liberal Unionist Party under the leadership of Chamberlain and Hartington. Since 1886 the Conservative Party has also been called the Unionist Party. The term Unionist is used throughout this article to describe both Liberal Unionists and Conservatives. 
the local Liberal Association and by the 1900 election, when he was defeated by Colonel Samuel A. Saddler who was standing for the constituency for the fourth time, he was firmly identified with the Liberal Party.

Saddler's election in 1900 was part of the considerable advance North Eastern Unionism made in that year, eleven Unionist candidates being returned in the area. ${ }^{1}$ Unionist strength appears to have been consistently stronger on Teesside than on Tyneside or in the Durham coalfield. ${ }^{2}$ Workers in the iron industry generally appear to have had no great commitment to Liberalism. Middlesbrough was, however, an exception in that Saddler's triumph was Unionism's solitary victory there in fifty-one years. That success can, perhaps, be simply attributed to the national swing to the Unionists, ${ }^{3}$ particularly marked in the ship-building ports and towns of the industrial NorthEast, together with a well respected local candidate who had long served the town in local politics and administration. ${ }^{4}$

The ILP members in Middlesbrough were early disenchanted with Havelock Wilson. Although in his first election he was supported by prominent members of the party such as Pete Curran, he was considered to have moved so far to the right by 1895 that Cunninghame Graham considered standing against him. ${ }^{5}$ By 1905 Wilson had declined to sign the LRC constitution and believers in a genuinely independent Labour representative had lost all faith in him. The Middlesbrough LRC, which was dominated by the ILP, was determined to find another candidate but the Trades Council stood by Wilson who was, of course, a leading trade unionist.

As Wilson was not a candidate endorsed by the TUC Parliamentary Committee, the Caxton Hall Concordat of February 1905, by which Liberal-Labour candidates officially endorsed by the Parliamentary

14 Liberal Unionists and 7 Conservatives (2 from both Newcastle and Sunderland).

2 Darlington returned a Unionist in 1895, 1900, 1906, December 1910; Stockton in $1892,1900,1906$. The county division of South East Durham returned a Unionist in $1886,1895,1900,1906$.

3 There was a national swing to the Unionists in terms of percentage of total votes cast although the Liberals, in fact, gained a handful of seats.

41900 Election: Electorate 17, 307; Col. Samuel A. Saddler (Unionist) 6760; Joseph H. Wilson (Liberal-Labour) 6705; Unionist Majority 55. Saddler, who had first stood for the constituency in 1878 , was the owner of a large chemical works and an ex-mayor of Middlesbrough.

5 In Wilson's own opinion his support for John Morley at the latter's byelection victory at Newcastle in 1892 had done him great harm with the ILP. "[...] by supporting Mr. Morley at Newcastle I made many enemies among the I.L. Party". J. Havelock Wilson, My Stormy Voyage through Life, Vol. 1 (1925), p. 265. 
Committee were not to be opposed by LRC candidates, did not apply but he was, nevertheless, a Liberal-Labour figure of some standing and the support of the Trades Council made it difficult for a LRC candidate to be put up against him. It was, in a sense, ironic that the Middlesbrough Trades Council should have continued to support Wilson, for the original decision by the LRC to allow trades councils to affiliate had been a gesture to illustrate independence from the $\mathrm{TUC}^{1}$ and over the country as a whole trades councils were much more socialist and militant than trade unions. In Middlesbrough, however, the Trades Council was a moderate body quite content with Wilson's Liberalism.

The main opposition in Middlesbrough to Wilson came from the two ILP branches, the Middlesbrough ILP and the South Bank ILP. The ILP was particularly pleased with its progress in South Bank; the branch there was considered "strong" with forty-five members in 1905 (it was founded in 1903), while there were also five ILP councillors and a local LRC, whose secretary was also President of the South Bank ILP. ${ }^{2}$ The national leadership of the ILP was as opposed to Wilson as were its Middlesbrough branches. Keir Hardie and Ramsay MacDonald, in particular, had a deep distaste for him. In June 1903 Wilson complained to the NEC of the LRC about MacDonald's opposition to him in Middlesbrough. ${ }^{3} \mathrm{He}$ had little right to complain in that, in the summer of 1903, he appears to have been the spearhead of a campaign against the LRC in the North East.

Middlesbrough had been thought of as a possible constituency in which to run a LRC candidate as early as $1900^{4}$ and it was also included in the list of seats drawn up by Herbert Gladstone on the 13th March 1903, in which he foresaw there would be no difficulty in making way for LRC candidates ${ }^{5}$ (Gladstone, however, was probably thinking in terms of Havelock Wilson being LRC candidate). In April 1903 Charles Coates of the Middlesbrough ILP wrote to MacDonald asking for advice on whether Charles Duncan or John Baker, both members of the ILP, would be the best choice as candidate for

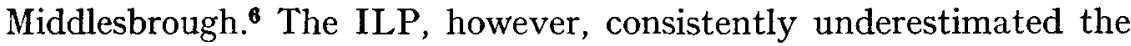

1 F. Bealey and H. Pelling, Labour and Politics 1900-06 (1958), p. 152.

${ }^{2}$ Mrs M. C. Hansen to J. R. MacDonald, July 4th 1903, Labour Party Letter Files, Transport House, London.

${ }^{3}$ LRC Executive Minutes, June 18th 1903, Pease Collection, London School of Economics. Also Wilson's letters to John Hodge, Chairman LRC, LPLF. The letters complain of MacDonald suggesting an alternative candidate and making disparaging remarks about Wilson.

4 Sub-Committee Report, May 31st 1900, LPLF.

${ }^{5}$ Herbert Gladstone Papers, British Museum, Ms 46106.

${ }^{6}$ C. Coates to J. R. MacDonald, April 23rd 1903, LPLF. 
support which Wilson enjoyed and, when a conference was arranged in Middlesbrough by the Trades and Labour Council to adopt a candidate, it became clear that, if Havelock Wilson accepted the constitution of the LRC, he would be that candidate. F. J. Iveson, the Secretary of the Trades Council, wrote to MacDonald on the 9th May 1903 that "the tendency is to favour Mr J. H. Wilson's candidature subject to that gentleman conforming to LRC rules. Other names mentioned are Mr Hodge, Mr C. Duncan and Mr Formie". ${ }^{1}$ The conference, consisting of the Middlesbrough and South Bank Trades Council and the two ILP branches, met on May 16th and its purpose was to select a Labour candidate to contest Middlesbrough under the auspices of the LRC. F. J. Iveson, reporting the result of the conference to MacDonald, told him that Wilson and Hodge had been nominated and asked to attend a further conference on June 27 th but that Hodge had subsequently withdrawn. There was, said Iveson, an enormous majority in favour of Wilson should he conform to the policy and programme of the NLRC but that, even if he did not, it was no use opposing him: "It is no use anybody coming against him if he means to go in the independent ticket."2

If Wilson had been prepared to accept the constitution of the LRC, as at various times it appeared he would, there is little doubt that he would have been LRC candidate for Middlesbrough in 1906. At the adjourned conferences called by the Middlesbrough Trades Council for June 17th, however, he came out definitely against signing. Ben Turner of the Woollen Weavers had attended the conference and wrote to MacDonald that Wilson refused to sign, largely on the grounds that he refused to deny himself the liberty of supporting liberal candidates in other constituencies. Turner continued:

"As he would not accept the constitution the Chairman promptly declared the conference at an end, as it had been called to accept a candidate who would accept the constitution. I was asked if the LRC would accept Mr. Wilson on the pledges he had given (i.e. to form one of a Labour group in parliament, act with it, abide by its own whips and help candidates of the LRC) and had to reply that the Newcastle conference was the authority and the committee could not go beyond it [...] I must say also that the bulk of the conference was much in favour of Mr. Wilson from the moment the meeting opened."3

1 F. J. Iveson to J. R. MacDonald, May 9th 1903, LPLF.

2 F. J. Iveson to J. R. MacDonald, June 6th 1903, LPLF.

${ }^{3}$ B. Turner to J. R. MacDonald, June 30th 1903. It would appear at first sight from the evidence of Turner's letter that the differences between Wilson and the LRC were minor and almost technical. Wilson agreed to be a faithful 
Having thus publicly refused to adhere to the LRC constitution, Wilson was, nevertheless, in a strong position. He had a strong following in Middlesbrough and his own organisation in the shape of the Middlesbrough Liberal-Labour Association. MacDonald was kept informed of the situation in Middlesbrough by a local ILPer, J. Arnott:

"Some time ago you asked for information regarding the persons or bodies 'running' Mr. J. H. Wilson. I then described the Liberal and Labour Association but could not say definitely that it was part of the Liberal Party. I now enclose a report of the first annual meeting of that august body. This report settles the question, as you will see in the second paragraph the Association is affiliated to the Northern Counties Liberal Federation. This fixes Mr. Wilson as a Liberal candidate."1

\section{III}

Despite Wilson's adoption as Liberal-Labour candidate and the fact that he had the tacit support of the Middlesbrough Trades Council, the ILP in the constituency were still determined to find a candidate to oppose him. In the summer of 1905 George Lansbury's candidature was strongly canvassed. Lansbury was in many ways a strange choice as an ILP candidate for Middlesbrough: he had no connection with the area, nearly all his political experience having been gained in London politics, he was an Anglican and the traditions of North Eastern radicalism were strongly non-conformist and for most of his political career he had been a member of the SDF and had only recently joined the ILP.

Mrs Marion Coates Hansen, Secretary to the Middlesbrough ILP, wrote to MacDonald that a joint meeting of the Middlesbrough and South Bank branches of the ILP, held on July 1st, had discussed the question of a parliamentary candidate for the borough "with a view to finally adopting $\mathrm{Mr}$ George Lansbury and submitting his name to the N[ational] A[dministrative] C[ouncil] for approval". She continued:

member of the LRC in almost every way except that he would not give up the right to support his Liberal and Liberal-Labour friends in other constituencies which was, of course, contrary to the "Newcastle Resolution" of 20th February 1903 , by which members of the executive, officials of affiliated organisations, members of parliament and candidates should not identify themselves with, or promote the interest of, "any section of the Liberal or Conservative parties". The differences between Wilson and the LRC were greater than this and it is likely that he deliberately went far further to meet the LRC requirements than he was really prepared to go, knowing that the Newcastle Resolution would prevent his acceptance by the LRC and that this could make the LRC look unreasonable and doctrinaire.

1 J. Arnott to J. R. MacDonald, February 11th 1905, LPLF. 
"After long deliberation it was ultimately unanimously agreed that the Committees meet to set the necessary machine in motion with that end in view [...] It is practically certain that Mr. George Lansbury's consent to contest this constituency (opposing the Tory and J. H. Wilson) will be obtained.

The election expenses (returning officer's fees etc.) are guaranteed by Mr. J. Fels. ${ }^{1}$

There has long been a feeling, deep-rooted and imperative, that J. H. Wilson has got to be opposed. The local branches have suffered injury long enough and have been searching for the right man to enter into such a contest for a long time."

Lansbury had recently been in Middlesbrough to address an unemployed demonstration which had been, according to Mrs Hansen, a great success. She found many factors favourable to a Labour candidate. In the first place ILP membership was increasing by "leaps and bounds" and the South Bank Branch formed in the last two years was now "strong" with forty-five members. In addition she felt J. H. Wilson was losing ground, due to his repudiation of the LRC and his support for men like Sir James Joicey and Sir Charles Mark Palmer, and pointed to the absence of prominent trade unionists from Wilson's platform at a recent meeting as an indication of this. The Liberal organisation was, she considered, nearly dead and South Bank, Wilson's "former stronghold", had got five ILP councillors and, in addition to its ILP branch, a "strong" LRC whose secretary was President of the South Bank ILP. ${ }^{2}$

MacDonald was soon contacted by Lansbury himself in respect of his candidature.

"I shall not attempt to do anything either the NAC or LRC disapprove. I am, however, certain Wilson is quite past praying for so far as the ILP or LRC is concerned."3

Lansbury confirmed that he was quite prepared to go to help another candidate in Middlesbrough if the NEC preferred someone else as he realised he would be a little suspect, having been in the ILP only a short time. ${ }^{4}$ MacDonald's reply was, however, encouraging. He wrote:

1 See below, p. 345.

2 Mrs M. C. Hansen to J. R. MacDonald, July 4th 1905, LPLF. Throughout Mrs Hansen's correspondence one can detect an air of boundless optimism and a tendency to overestimate support, often the hallmark of the activist in extremist politics.

${ }^{3}$ G. Lansbury to J. R. MacDonald, July 6th 1905, LPLF.

${ }^{4} \mathrm{G}$. Lansbury had previously been a member of the SDF. 
"I am altogether in favour of clearing Wilson out. The more I have to do with the Labour Movement, the more necessary does it seem that our candidates should be men whose character and conduct can bear the light of day". ${ }^{1}$

The NEC secretary was, in fact, to give every encouragement to Lansbury's candidature.

On September 30th a conference of ILP members and trade unionists who wished for a Labour candidate met in Middlesbrough and invited George Lansbury to be their candidate. As the North Eastern Daily Gazette put it:

"An important decision was reached by the Independent Labour Party of Middlesbrough and South Bank on Saturday. At a meeting attended by a fairly large number of trade unionists it was resolved to invite Mr. G. Lansbury to contest the constituency in opposition to the sitting member Sir Samuel Saddler and the accepted Liberal-Labour candidate Mr. J. Havelock Wilson."2

In the words of Lansbury's biographer, his son-in-law Raymond Postgate, "Instead of staying to fight the General Election in Bow, where he was well known and might well have carried the seat, he persuaded himself it was his duty to leave that seat to an apparently well intentioned and progressive Liberal and to go up to Middlesbrough to turn out Havelock Wilson, the Seamen's leader". ${ }^{3}$

Lansbury does not appear to have had many links with the North Eastern ILP and, indeed, his political and religious background, together with his advanced views on many questions, would seem to have made him a candidate singularly ill suited to his constituency. One reason for his candidature was a strong antipathy to Havelock Wilson, whom he saw as having betrayed his early independent Labour position and whose union policy of co-operation with the shipowners he disliked. There was also a personal link with Mrs Marion Coates Hansen, secretary of the conference which adopted him, via Walter Coates, her relation, who was a business partner of the wealthy soap manufacturer Joseph Fels and, like him, a generous financial supporter of Lansbury. It is also certain that from the beginning of his candidature Lansbury enjoyed the enthusiastic support of Keir Hardie, who had been an implacable opponent of Wilson's for some years and was eager to see him unseated.

Lansbury's first major setback in the constituency was his failure

1 J. R. MacDonald to G. Lansbury, July 7th 1905, LPLF.

2 North Eastern Daily Gazette, October 2nd 1905.

3 R. Postgate, George Lansbury (1951), p. 76. 
to gain adoption as an official LRC candidate. Despite considerable sympathy with Lansbury and dislike of Wilson among its members, the NEC found itself unable to give Lansbury its official backing. Although influenced by the awkwardness of opposing a candidate like Wilson, who enjoyed such strong Liberal and Trade Unionist backing, this decision was technically made on the grounds that the Middlesbrough LRC which put forward Lansbury's candidature was not an affiliated body. Mrs Hansen communicated the decision of the conference which adopted Lansbury to the NEC but, as the Middlesbrough Trades and Labour Council had not supported the conference and was an affiliated body, the NEC could only resolve that "the Committee should do nothing until an affiliated organisation took the matter up". ${ }^{1}$

On December 14th, at the last meeting of the NEC before the General Election, the Middlesbrough situation was once more discussed and letters from both the local LRC and the Trades Council were read. The Middlesbrough LRC claimed that the Trades Council did not cover the whole constituency and that, therefore, the Executive should affiliate the LRC. The Trades Council merely reiterated the case against opposing Havelock Wilson and, arguing against Lansbury's candidature, asked the Executive to take no part in the Middlesbrough contest. The NEC resolutions clearly show its members' sympathies, the Secretary being instructed to make further enquiries and reply accordingly to the LRC letter, while the Trades Council were told bluntly that "the statements in the letter are inaccurate". An application from Lansbury's Election Committee for the use of party literature was turned down gently: "owing to the position in the constituency we cannot give a supply, but the sub-committee may do so if the situation alters". ${ }^{2}$

It seems likely that the NEC or, at any rate, its ILP members were by this time looking for a way to support Lansbury and replace the Trades Council with the local LRC as the affiliated body. A letter from Ramsay MacDonald to Lansbury sets out the position:

"We have been asked by the Middlesbrough LRC to endorse you, and at the same time have been requested by the Committee to allow it to affiliate with us under our rule which provides that in constituencies not completely covered by a Trades Council we shall affiliate local labour organisations that are responsible for

${ }^{1}$ LRC Executive Minutes, October 2nd 1905, Pease Collection.

2 LRC Executive Minutes, December 14th 1905, Pease Collection. The subcommittee referred to is the sub-committee left in London by the NEC to look after party affairs during the election, when many prominent members would be fighting in provincial constituencies. 
the political work in the whole of the constituency. This application has come so late that it does not give us time to enquire and settle before the election whether the position in Middlesbrough enables the Middlesbrough LRC to come under that rule. Until that technical difficulty is out of the way, my committee is debarred from taking any action. You are therefore quite justified in stating that it is not owing to any demerits in your candidature that your name has not been entered on our list but simply that we have not been able to consider certain preliminary questions of a technical nature. There is nothing in the situation at Middlesbrough which would prevent us placing you on our list if these preliminary questions were satisfactorily answered. The whole question is still open and indeed it has been referred to a sub-committee."1

MacDonald added a postscript to the effect that he would be pleased to help Lansbury if his own election came at such a time as to release him.

Shortly after the LRC decision, the National Administrative Council of the ILP reluctantly followed the LRC example and refused to adopt Lansbury as an official candidate. Mrs Hansen's feelings about this overflowed in a letter to MacDonald.

"If there is nothing to be done, then really both NAC and LRC ought to have said that on no account must Wilson be fought. It was unfair not to say so frankly [...] are we to go on with the fight? I wish Hardie had never come. All our members were taken up with his advice and now I am the sole possessor of news which will weaken all our garrison walls. The NAC will never be foolish enough to make that decision public! and what am I to do? It is too bad with a man like Lansbury as candidate - so honest, sincere and worthy of a seat in the House of Commons." 2

On December 27th the Trades Council dropped the last pretence of neutrality in the conflict and came down firmly on the side of Wilson, deciding by 26 votes to 7 to adopt him as its candidate.

It was lack of time rather than anything else which prevented Lansbury running as an official LRC candidate. The local LRC had played their trump card, the claim that the Trades Council did not cover the whole constituency, too late in the day and there was not time to consider the case before the election. In the course of 1907

1 J. R. MacDonald to G. Lansbury, December 23rd 1905, Lansbury Papers, Vol. 2, London School of Economics.

${ }^{2}$ Mrs M. C. Hansen to J. R. MacDonald, December 22nd 1905, LPLF. 
the Middlesbrough LRC was affiliated ${ }^{\mathbf{1}}$ and in July 1907 the Trades Council was removed from the list of affiliated bodies after an angry exchange of letters. ${ }^{2}$

Lansbury was, nevertheless, denied the official backing of the LRC and, although it is difficult to estimate the extent to which this contributed to his coming a poor third in the election, it was certainly a blow to some of his supporters. His agent, Mrs Hansen, in a letter of the 24th December, admitted that, while the ILP men were solid, there was a tendency for trade union supporters to "hang back until the LRC pronounced". By this time she knew that they were not going to get LRC backing and expressed her fear that they were going to "look foolish", having started out endeavouring to get that ticket. Mrs Hansen was, undoubtedly, right in feeling that if Lansbury had started out purely and simply as a Socialist candidate it would have made their position more logical. ${ }^{3}$ It was as a Socialist that he now stood and, though he may well have regretted the tactical advantage that he had lost, it is likely that Lansbury welcomed the greater freedom that this gave him as his views on many questions were at variance with the LRC.

\section{IV}

Although he was the outside candidate in the sense that both the others were well known in the constituency, having dominated its politics for years, Lansbury appears to have had a well organised campaign. In the person of Mrs Hansen he had an enthusiastic though, at times, somewhat excitable agent. Her letters to Lansbury, who was not in the constituency for much of the early stage of the campaign, reveal her as an ardent feminist, a great admirer of Lansbury and a hardworking and conscientious agent with a tendency, perhaps, to become too absorbed in the minutiae of electioneering. Her initial request to be appointed agent reveals her ardent support for Women's Rights: "Will there be any legal objection to my acting as your Agent? You must not forget that I am not even 'a person' in the eyes of the law as far as elections etc. are concerned." 4 To a later letter she appended the postscript "Thanks for the strong appeal for votes for women". ${ }^{5}$ Her letters deal with the speaking programmes arranged for Lansbury,

${ }^{1}$ LRC Executive Minutes, December 19th 1906, Pease Collection.

${ }^{2}$ LRC Executive Minutes, July 24th 1907, Pease Collection.

${ }^{3}$ Mrs M. C. Hansen to G. Lansbury, December 24th 1905, Lansbury Papers.

4 Id., December 7th 1905.

5 Id., December 8th 1905. It is doubtful whether, in a heavy industrial constituency like Middlesbrough, Lansbury's support for "Women's Rights" was an advantage. 
with the possibilities of the catholic vote, with the desirability or otherwise of votes of confidence at meetings and with her efforts to win the support of prominent local councillors.

Lansbury appears to have had a campaign headquarters established, at his Central Committee Rooms in Newport Crescent, before the other candidates and Mrs Hansen kept a shrewd eye on the opposing organisations. "Wilson has no Committee Rooms yet, neither has Saddler. Wilson has still no organisation whatever. Saddler has a splendid organisation - Conservatives always have haven't they?"' Some days later she wrote: "We are working all hours here. Paid workers have gone home but almost a dozen voluntary workers are at it now though it is turned eight o'clock."2

One thing that Lansbury was not short of was money. He enjoyed the generous support of Joseph Fels who seems to have underwritten the not inconsiderable costs of the campaign. Fels was a Jewish American capitalist who had made a fortune (out of "Fels-Naphtha" soap) and used it to further left wing causes. He was not a socialist but a Henry Georgite, believing that a tax on land values was the basic solution to social evils but, having been introduced to Lansbury by Keir Hardie, he consistently helped him and relied on his advice. Fels's money founded the Vacant Land Cultivation Society and he helped support Laindon Farm Colony and Hollesby Bay. ${ }^{3}$ His most famous donation was a loan of $£ 500$ which, after consulting Lansbury, he lent to enable the Russian Social-Democratic Conference of 1907 to complete its agenda. It was at this conference that Lenin and the Bolsheviks carried the day against Martov and the Mensheviks. ${ }^{4}$ According to Postgate he used to reply when challenged, by indignant rivals who disapproved of his egalitarian views, to give away his money: "I shall go on making as much money as I can; and I will use it to prevent people like you and me being allowed to do so any longer."5

Walter Coates, Fels's business associate and friend, was almost equally generous and frequent injections of money were pumped into Lansbury's campaign. Mrs Hansen's letters give the impression that money was spent fairly freely: "Can you get Walt to send $£ 30$ ?" and "We can spend about $£ 1,000$ on the campaign here if we like. Wilson

1 Id., December 7th 1905.

2 Id., December 1905.

3 Laindon Farm Colony and Hollesby Bay were both institutions designed to make work for the unemployed.

4 The sequel to this episode is that Fels got his money back after the Bolshevik Revolution, an outcome he can scarcely have anticipated.

5 R. Postgate, George Lansbury, p. 68. 
spent about $£ 850$ last time. Saddler spent about $£ 1,000$."1 When a supporter, a certain Councillor Carey, lost his job as an insurance man she wrote asking Lansbury to do something for him as he "would be an invaluable worker in the election if only he were rid of his financial troubles". ${ }^{2}$ Walter Coates in a letter to Mrs Hansen said that, while he could not be responsible for very much towards Carey's support and whatever he could give would have to be on a year to year basis, he would give $£ 25$ a year towards a fund. He added that "if the Middlesbrough election doesn't cost more than about six or seven hundred Joe might be willing to subscribe $£ 50$ for next year". ${ }^{3}$ In the same letter Coates said that he had had a note from Lansbury asking him to wire $£ 100$ to her and had done so. When the Liberals accused Lansbury of being backed by "Tory Gold" they were wrong; he was, however, backed by philanthropic capitalism.

At a time when, nationally, the electoral alliance between Liberal and Labour stood firm, Lansbury was vulnerable to the charge of splitting the anti-Unionist vote. Many ILP stalwarts in the North East had, however, little time for the, as yet, unavowed GladstoneMacDonald Agreement and, in Chester-le-Street, Stockton and Jarrow, contests were taking place between Liberal and Labour although only the latter two constituencies had official LRC candidates. Lansbury was one of the few candidates in the country, among them the eight SDF candidates and one other independent Socialist, who could really claim to be apart from the Conservative-Liberal struggle, though his position was qualified by the support given to him by Ramsay MacDonald and Keir Hardie. In Middlesbrough the ILP were so far from being in sympathy with a Liberal alliance that they publicly declared they would rather be represented by a Tory than Wilson.

It is not surprising that a considerable degree of personal animosity distinguished the contest between the Socialist and Liberal-Labour candidates, although both managed to remain on good terms with Sir Samuel Saddler. The Unionist candidate fought the election in defence of the late Unionist Government's record and as a firm advocate of Tariff Reform. Both he and Wilson, for all that the LiberalLabour candidate's election address included radical measures such as the taxation of land values, abolition of the House of Lords' veto

1 The maximum legal expenditure in a constituency with 20,000 registered voters (Middlesbrough had 20,332) should have been, in accordance with the Corrupt and illegal Practices Prevention Act (1883), £920.

2 Mrs M. C. Hansen to G. Lansbury, December 8th 1905, Lansbury Papers, Vol. 2.

3 Walter Coates to Mrs M. C. Hansen, December 8th 1905, ibid. 
and Home Rule for Ireland, concentrated mainly on the fiscal issue in their debate with each other.

Lansbury also dealt with that issue, being opposed to Tariff Reform, but he gave it far less prominence, being concerned to demonstrate that both tariff reforming Unionists and free trading Liberals were equally opposed to the interests of the working class and that only a really independent Labour or Socialist candidate could represent those interests. Lansbury said he would go away "if Mr. Wilson will sign the constitution of the NLRC to sit apart and vote apart from the Liberals and the Tory capitalist party". 1 Wilson retorted that he was "not prepared to be intimidated". Lansbury had been "rushed up" and all his candidature could do was let in the Tory. "They [Lansbury's supporters] have already said they would much prefer Sir Samuel Saddler to myself", said Wilson, and on other occasions he alleged that the extreme section of the ILP were "really Tories at heart". Lansbury was posing as a LRC candidate when he had no right to do so and the people most active in Lansbury's candidature were "people connected with shipping whose tender feelings he had touched on in his fight for the rights of his fellow men". ${ }^{2}$

From the Liberal point of view Lansbury's electoral record was indeed a disastrous one. It could be argued that by standing in threecornered contests in Walworth in 1895, at both a by-election and the general election of that year, he had split the progressive vote and allowed the Tory to win, and that when in 1900 he had stood for Bow and Bromley, previously a Liberal seat, and the Liberals had not intervened, he had once more been defeated by a Tory. ${ }^{3}$ The point was of course that to Lansbury there was no such thing as a "progressive vote", if that included the Liberals, and to be defeated by a Tory was to him no worse than to be defeated by a Liberal.

The level on which the debate between Lansbury and Wilson was conducted was not at all times a high one. Lansbury, for instance, claimed that he was the only candidate who had not drunk champagne in the Mayor's Parlour after the nomination ceremony. Wilson protested that this was an attempt to win the Temperance Vote and that he had not in fact drunk champagne. In this instance Lansbury apologised to Wilson. The Seamen's leader did, however, appear to have a knack for becoming involved in feuds. He accused James Knott, the Unionist candidate for Tyneside Division, of employing

1 North Star, December 14th 1905.

2 North Eastern Daily Gazette, December 22nd 1905.

3 Northern Echo, January 12th 1906. Contains an attack on Lansbury's electoral record. 
alien labour on his ships, to which Knott replied by betting Wilson $£ 200$ that he did not. ${ }^{1}$

But what really raised the temperature was Keir Hardie's visit to Middlesbrough to support Lansbury. Hardie not only disliked Wilson's politics but felt that he was too good a friend of the shipowners to be a genuine leader of the seamen. ${ }^{2}$ Wilson would, according to Hardie, "do as he had done before, fight Labour and support capitalists at every opportunity" ${ }^{3}$ The Liberal-Labour candidate counter-attacked strongly, saying that Keir Hardie would have been better called "Queer Hardie". ${ }^{4} \mathrm{He}$ criticised Hardie's frequent absence from the House of Commons and his poor record of voting on issues concerning working men, and carried the war into the enemy's camp by sending a manifesto, on behalf of the Seamen of the United Kingdom, to Merthyr Tydfil where Hardie was defending his seat. This manifesto complained of Hardie's interference, along with the ILP, with Wilson's candidature in 1900 and again at the present election. It accused Hardie of introducing George Lansbury in opposition to himself with the object of keeping him out and letting a Tory in, thereby robbing the workers of Middlesbrough, and sailors generally, of representation in the House of Commons. He appealed to Merthyr working men to support H. Radcliffe, Liberal and shipowner, and show their disapproval of Hardie's ruinous policy towards Labour. ${ }^{\mathbf{5}}$

Lloyd George happily joined in this onslaught when he came to Middlesbrough and spoke in support of Wilson on the 8th January. Hardie, he said, was "exalting personal cantankerousness to the level of a personal faith". 6 Wilson, said Lloyd George, was the "sort of man I can tiger hunt with [...] there are some people I would not go ratcatching with", and was a Labour man who knew the needs of Labour, whilst Keir Hardie and his friends were trying to turn him out purely because he was willing to co-operate with the friends of the Labour cause. ${ }^{7}$ Lloyd George's visit illustrates the importance attached by the Liberal Party to Wilson's campaign and to the threat from the left generally. In nearby Stockton-on-Tees, where there was also

1 Shields Daily News, January 12th 1906.

2 S. Maccoby, in English Radicalism, the End? (1961), stated that Hardie believed that Wilson "had not been above selling the seamen on occasion for a private consideration from their employers". Certainly allegations about Wilson's financial affairs were common, though emphatically denied by him.

3 Northern Echo, January 12th 1906.

4 North Eastern Daily Gazette, December 22nd 1905.

5 Shields Daily News, January 17th 1906.

' Shields Daily News, January 17th 1906.

7 Times, January 10th 1906. 
a three-cornered fight, the Liberal candidate received the personal support of Asquith.

The evidence would tend to suggest that Lansbury's campaign was none too well received. He was in many respects far too advanced a candidate for the constituency. He argued for land nationalisation, housing schemes, a minimum wage, votes for women, old age pensions, abolition of a hereditary second chamber, as well as being in favour of Free Trade and Home Rule for Ireland. Where Lansbury differed from Labour candidates in the North East was not only in the advanced views he held but in the fact that he attacked Liberalism as savagely, or perhaps more savagely, as Unionism, an attitude which may well have seemed idiosyncratic in an area where the roots of the ILP were in nonconformity and Liberalism, however far ILPers might consider they had moved from those roots. On January 11 th he made a strong attack on Liberalism as represented by Morley's speech, at Arbroath, which had opposed the principle of the state, guaranteeing a standard living wage as an "unsound and dangerous principle". "Liberalism", Lansbury said, "is diametrically opposed to the Labour Movement", and the Middlesbrough Election Neres, his paper, put forward the slogan "Labour is Labour and Liberalism is Liberalism, and never the twain shall meet". He argued that both parties, Liberal and Conservative, served one set of capitalist interests or another: "For instance all the shipowning and other manufacturing interests are joining the Liberal party now [...] because their capitalistic bread is buttered or buttered and treacled on that side."

The Education Question was one aspect of policy where Lansbury differed not only from Liberalism but from almost every LRC candidate in the area. He was in many ways sympathetic to the 1902 Act, seeing it as a step forward. All education, he believed, should be a charge on the national exchequer but he was in favour of both sectarian and non-sectarian education being financed in this way and, as an Anglican, was sympathetic to Church of England and Roman Catholic Schools. The Liberals, he said, "opposed free education till it was bestowed by the Tories", "they are rallying to their side the passive resisters who wish in spite of everything they say to the contrary to put and keep unsectarian religious teaching on the rates and deny the sectarians the same right". ${ }^{1}$

This attitude to education was obviously likely to cost Lansbury some non-conformist votes but he could hope to do well with the not inconsiderable catholic vote. Mrs Hansen estimated that the Catholic Electoral Association influenced about 3,000 votes and she had hopes

1 Middlesbrough Election News, January 6th 1906, Lansbury Papers, Vol. 2. 
that these votes might come their way as "Redmond had pronounced that no vote has to be given to anyone who is not right on the Education Question". ${ }^{1}$ Both Lansbury and Saddler spent much time bidding for the sectarian vote but, in the event, T. P. O'Connor and Redmond advised all Irishmen to vote for the seamen's leader. ${ }^{2}$

Unlike the other two candidates, Lansbury could not rely upon a sympathetic press coverage from at least a section of the local newspapers. In fact the Unionist press appears to have covered his meetings more fairly and objectively than the Liberal papers. The North Eastern Daily Gazette, a Middlesbrough newspaper, was particularly biased: according to his own Middlesbrough Election News, the Gazette was prepared to report a "small" Lansbury meeting of fifty or seventy people or an "enthusiastic and satisfactory meeting", for Wilson, of seven people. The Unionist North Mail was much more favourably inclined than the Northern Echo and contrasting accounts of a meeting on December 30th appeared in both, the Echo reporting that only a few were present, many of whom were opposed to Lansbury so that his supporters didn't dare risk a vote, while the Mail reported that a vote of confidence was passed with only five dissentients. ${ }^{3}$

Votes of confidence at meetings were, however, a real problem, a sign perhaps that Lansbury's campaign lacked sufficient support to pack the halls with his own supporters. The reporter of the North Star, a Unionist paper, had earlier doubted whether the vote of confidence had been carried at a meeting in the Town Hall on December 13th. ${ }^{4}$ The practice of votes of confidence at the end of every meeting was, of course, a dangerous one and disapproved of by Mrs Hansen, who thought that they were usually done badly; as she remarked with feminist superiority, "Those men make a mess of everything!"5

By the time Middlesbrough went to the polls the landslide to the Liberals over the country as a whole had already become apparent, though Sir Samuel Saddler still professed confidence that he could win against the national swing. When the result was announced, on a large screen outside the Town Hall, it was apparent that not only had Saddler not held on to his seat but that Lansbury had made little inroad into either the Unionist or Liberal vote. There had been a

1 Mrs M. C. Hansen to G. Lansbury, December 1905, Lansbury papers, Vol. 2. This letter is undated but was probably written about the third week in December.

2 In Jarrow the Irish were similarly advised by their leaders to vote for the Liberal, even though Pete Curran, the LRC candidate, was Irish.

${ }^{3}$ Middlesbrough Election News, January 2nd 1906.

4 North Star, December 14th 1905.

${ }^{5}$ Mrs M. C. Hansen to G. Lansbury, December 24th 1905, Lansbury Papers, Vol. 2. 
heavy poll and Havelock Wilson had regained Middlesbrough with a majority of 2,381; Lansbury came bottom of the poll with only 1,380 votes. ${ }^{1}$ The Socialist candidate also ended the campaign by becoming seriously ill. He had toured the wards the day before polling day and ended up in the market place "more dead than alive"' and was afterwards confined to bed for some weeks.

\section{V}

Whether Lansbury's incursion into the politics of North East England ever stood much chance of success may be doubted. Both Saddler and Wilson had a longstanding association with the constituency and political support which had been built up for many years, while the latter was one of the most prominent trade unionists in the area. Lansbury was a stranger and had to build up both an electoral organisation and support from very little. His failure to gain acceptance as an official LRC candidate must have made his chances even slimmer. His advanced Socialism was no asset, even in a town which had perhaps some of the worst housing conditions in England, ${ }^{3}$ while his lack of sympathy with non-conformity was another handicap in a town with a strong non-conformist tradition. ${ }^{4}$

Lansbury's intervention in the Middlesbrough contest is important for the light it throws on the relations between Liberalism and the Labour movement in the North East. The alliance between the Liberal Party and the LRC, in the general election of 1906, papered over and obscured the major differences between the two parties while it also postponed clashes, within the Labour movement itself, as to the attitude to be taken towards Liberal-Labour MPs of the Havelock Wilson type. In the North East, hostility between Liberalism and Labour was stronger than elsewhere in England and, although neither Havelock Wilson nor the mining MPs, Burt, Fenwick and

1 Electorate 20,332. Total Poll 17,501. J. H. Wilson (Lib. Labour) 9,251

$$
\begin{array}{ll}
\text { S. A. Saddler (Unionist) } & 6,870 \\
\text { G. Lansbury (Socialist) } & 1,380 \\
\cline { 2 - 2 } \text { Lib-Lab Majority } & 2,831
\end{array}
$$

2 R. Postgate, George Lansbury, p. 76.

3 The Medical Officer of Health report 1900 had found no toilets or even sinks in many houses, with all refuse tossed into the front street, while 168 persons were found to be living in 18 houses.

4 Asa Briggs, in Victorian Cities (1963), comments on the variety of religions in Middlesbrough but also says, p. 261: "the attempt to keep rates down or to defend Nonconformity and temperance remained the main elements at municipal elections". 
John Wilson, ${ }^{1}$ were opposed by LRC candidates, time was running out for the alliance in the area. Within the lodges of the mining unions ILP activists were hard at work and, by the general elections of 1910 , both the Durham and Northumberland mining unions would be affiliated to the Labour Party, though their elderly "Lib-Lab" MPs would still have the prestige and following to hold their own. In Jarrow, in 1906, Pete Curran was standing as LRC candidate against a Liberal, as was F. Rose in Stockton, whilst in Chester-leStreet, J. W. Taylor, a member of the ILP and the Miners' Union candidate, was also standing against a Liberal. ${ }^{2}$ The Middlesbrough election illustrates the fragility of the electoral alliance so far as the ILP was concerned both regionally and nationally. Granted that Havelock Wilson was a candidate who had for long incurred ILP hostility, the fact remains that not only the ILP in Middlesbrough but also two of the party's most prominent national leaders, Hardie and MacDonald, the latter the very architect of the electoral alliance, were on Lansbury's side.

This is not to say that working class voters in the North East were tired of either Liberalism or Liberal-Labourism and, indeed, the result of the Middlesbrough election and many subsequent elections in the area go to show that they were not. Lansbury might well be one of the few candidates in 1906 who could stand apart from the clash between the Liberal and Unionist parties but his own experience would suggest that the Middlesbrough voters thought in terms of that conflict. In his book Looking backwards and forwards, he commented that the steelworkers were "in the main strongly opposed to my candidature because they were afraid [...] I would let the Tory in!" Liberalism was still strong among working class voters in the North East and, indeed, in 1910 the Liberal Party was able to mount a successful counter attack in Labour held seats. By this time, however, LiberalLabourism had become something of an anachronism, the remaining "Lib-Lab". MPs being straightforward Liberals in all but name. It is significant that, even with the departure of Havelock Wilson, Middlesbrough remained firmly Liberal in 1910, the Labour candidate in the January election only managing to double Lansbury's meagre vote.

1 J. W. Taylor (Chester-le-Street) and J. Johnson (Gateshead) were also Miners' Union candidates but Taylor was a member of the ILP and Johnson to the left of the "Lib-Labs".

${ }^{2}$ Curran had a straight fight with a Liberal while Rose and Taylor, who was not a LRC candidate, fought three cornered contests. 